\title{
A revision of the genus Neofabricia (Myrtaceae)
}

\author{
J.R. Clarkson and Joy Thompson
}

\begin{abstract}
Clarkson, J.R. (Botany Branch, Department of Primary Industries, P.O. Box 1054, Mareeba, Queensland, 4880) and Joy Thompson (National Herbarium of New South Wales, Royal Botanic Gardens, Sydney, Australia 2000) 1989. A revision of the genus Neofabricia (Myrtaceae). Telopea 3(3) 291-300. The genus Neofabricia, endemic to Cape York Peninsula, is reviewed. Three species, $N$. mjoebergii, $N$. myrtifolia and $N$. sericisepala, are described, $N$. sericisepala as a new species. The distribution of each species is mapped and a key for their identification provided.
\end{abstract}

\section{Introduction}

The genus Neofabricia J. Thompson (1983) was erected to accommodate $N$. myrtifolia (Gaertner) J. Thompson and N. mjoebergii (Cheel) J. Thompson, two species previously referred to Leptospermum Sect. Fabricia Benth. (1867), as $L$. fabricia Benth. and L. mjoebergii Cheel.

Recently a third species of Neofabricia has been found that differs in its morphology and ecological requirements from the known species. We now give a formal treatment of this genus to summarise our knowledge of the group.

Neofabricia J. Thompson, Telopea 2(4): 380 (1983)

TYPE: N. myrtifolia (Gaertner) J. Thompson.

Synonym: Fabricia Gaertner, Fruct. Sem. Pl. 1:175, t.35, (1788), non Adans. (1763), nec Scopoli (1777), nec Thunb. (1779), nom. illeg.

TYPE: Fabricia myrtifolia Gaertner.

Shrubs or small trees with fibrous, longitudinally fissured bark. Leaves alternate, spirally arranged, simple, entire, sessile or very shortly petiolate, with numerous oil glands readily visible with a lens; venation acrodromous with $3-5(-7)$ basal nerves, reticulate, the nerve islands elongate. Inflorescence an axillary bracteolate monad (rarely a triad), in leaf axils or on condensed shoots where a single flower and the terminal shoot bud are surrounded by imbricate bracts in the bud; bracteoles opposite. Flowers sessile or very shortly pedicellate, regular, 5-merous, polypetalous, bisexual; hypanthium broadly funnel-shaped to hemispherical, pubescent; sepals broad, persisting at least on young fruit; petals 5, imbricate in bud, yellow, white or cream, glabrous; stamens numerous, arranged in several irregular rows, with the outermost usually the longest, on a somewhat undulate disc, their disposition suggesting that there are 5 bundles each centred on a petal; filaments filiform, tapering at the apex; connectives with a prominent terminal gland; anthers dorsifixed, non-versatile, 2-celled, opening by longitudinal slits; ovary inferior, 5-12-locular, with narrow axile placentas bearing 2 rows of ovules; top of the ovary raised, with lobes above each loculus, pubescent; style terete, well inset in the top of the ovary; stigma terminal, simple, discoid, sometimes set obliquely on the style. Fruit a 
multilocular capsule, almost spherical before dehiscence; valves exserted, splitting along the upper margins. Seeds irregularly ovate, flattened, usually 1 per loculus, developing from one of the lower ovules with the remaining ovules of that loculus aborted and fusing to form a pale scarious wing.

Distribution: A genus of 3 species confined to Cape York Peninsula (Cook district), North Queensland (Fig. 1).

Notes: Neofabricia appears to be a member of the Leptospermum suballiance of Briggs and Johnson (1979) but its relationship to other genera of that group has not been studied. The features which distinguish Neofabricia were discussed by Thompson (1983). They include the ontogeny of the wing on the seed, the anther attachment and the arrangement of the stamens.

\section{Key to the species}

1 Leaves less than $1.5 \mathrm{~cm}$ long. Flowers white or cream. Base of fruit broadly conical, $4 \mathrm{~mm}$ or less in diameter ............................. 1. $\mathbf{N}$. mjoebergii

$1^{*}$ Leaves more than $1.5 \mathrm{~cm}$ long. Flowers yellow. Base of fruit broadly cupular, more than $4 \mathrm{~mm}$ in diameter

2 Sepals densely sericeous. Leaves $2-4(-5) \mathrm{mm}$ wide. Fruit 5-8-locular 2. N. sericisepala

2* Sepals glabrous except on margins or sparsely pubescent, never densely sericeous. Leaves (4-)6-10(-13) mm wide. Fruit 8-12-locular

3. N. myrtifolia

1. N. mjoebergii (Cheel) J. Thompson, Telopea 2(4): 381 (1983).

BASIONYM: Leptospermum mjoebergii Cheel, J. \& Proc. Roy. Soc. New South Wales 53: 120 (1919).

Holotype: QUeENSLAND: Coleman River, Dr E. Mjöberg NSW 180571, 9.1913 (NSW).

Shrub or small tree to $10 \mathrm{~m}$. Bark tight, grey or grey-brown. Branchlets villous, glabrescent. Leaves sessile, narrowly elliptic to oblanceolate or obovate, $6-10(-14) \mathrm{mm}$ long, 2-4(-6) $\mathrm{mm}$ wide, glabrous or puberulent; base attenuate to cuneate; apex acute to acuminate. Flowers borne singly or rarely in triads in the upper leaf axils, subtended by a pair of bracteoles; bracteoles leaf-like, green, puberulent, persisting on young fruit but at length deciduous; hypanthium broadly funnel-shaped, 2-3 $\mathrm{mm}$ long, 3-3.5 $\mathrm{mm}$ diam. at the apex, puberulent; sepals broadly ovate, $2-3 \mathrm{~mm}$ long, glabrescent; petals almost orbicular, 3.5-4 mm long, white or cream. Filaments $1.5-4.5 \mathrm{~mm}$ long; terminal gland spherical; anther cells diverging, separate, on opposing sides of the gland, 0.4-0.5 mm long. Ovary 5-7-locular; top of the ovary raised, strongly lobed, villous; style 3.5-4.5 mm long; stigma $0.4-0.5 \mathrm{~mm}$ wide, as wide as or slightly wider than the apex of the style. Fruit 3-4 mm diam., villous, glabrescent; base broadly conical; valves much longer than the cupular base. Seeds c. $1.5 \mathrm{~mm}$ long excluding the wing, c. $1 \mathrm{~mm}$ wide, dark reddish brown; wing $2-3 \mathrm{~mm}$ long, c. $1.5 \mathrm{~mm}$ wide. (Fig. 2c \& Fig. 4g-l).

Flowering AND Fruiting PERIODS: Flowering occurs from August to October. Most fruit fall shortly after the seed has been shed but a few are sometimes retained until flowering the following year. 
Distribution: Central inland areas of Cape York Peninsula southwest of Princess Charlotte Bay between latitudes $14^{\circ} 30^{\prime}$ and $15^{\circ} 30^{\prime}$ South.

ECOLOGY: Occurs in open forests and woodlands dominated by Eucalyptus and Melaleuca species, usually associated with white sands. The understorey of these communities is often shrubby.

Conservation STATUS: The rating $2 \mathrm{R}$ by Thomas and McDonald (1987) is probably an accurate assessment of the conservation status of this species. The flowers, however, are insignificant and the plant could have been overlooked by collectors. Although no collections have been seen from within a proclaimed conservation reserve, the species almost certainly occurs within the Lakefield National Park.

NoTES: This species is readily distinguished from other Neofabricia species by its habit, its small, narrow leaves, white or creamy coloured flowers and its small fruit. In the field it could be confused in general appearance with the more widespread and common Thryptomene oligandra. This may account for its poor representation in herbaria. The opposite leaves of the $T$. oligandra serve to distinguish it.

SPECIMENS SEEN: 16.

SELECTED SPECIMENS: $13.7 \mathrm{~km}$ N of Wakooka on the track to Cape Melville, Clarkson 7313, 31.7.1987 (BRI, NSW, MBA); near Musgrave, Hyland 10066, 15.9.1979 (QRS); 54 $\mathrm{km} \mathrm{E}$ of Edward River on the Musgrave to Edward River Road, Clarkson 3503,

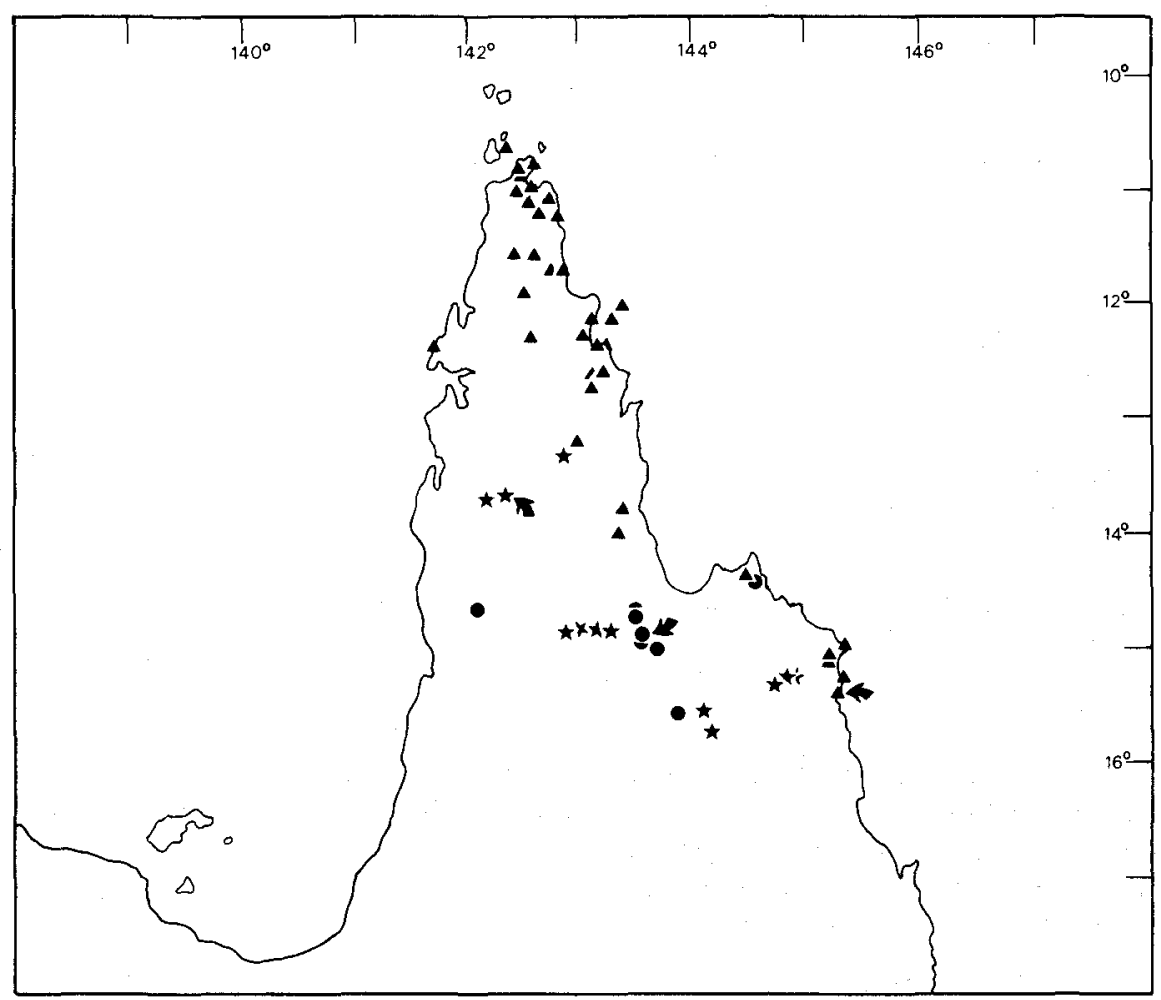

Fig. 1. Distribution of Neofabricia species. N. mjoebergii $O, N$ sericisepala $\star, N$. myrtifolia $\boldsymbol{\Delta}$. Arrows indicated type localities. 
10.10.1980 (BRI, CANB, K, L, MBA, MEL, MO, NA, NSW, NT, PERTH, QRS); between Morehead and Hann Rivers, Brass 19983, 29.8.1948 (BRI); 7.2 km NW of Kennedy River crossing on the Fairview to Kimba road, Clarkson 3184, 20.4.1980 (BRI, $\mathrm{K}, \mathrm{MBA}, \mathrm{MO}, \mathrm{NSW}$ ).

\section{N. sericisepala J. Clarkson \& J. Thompson sp.nov.}

A $N$. myrtifolia (Gaertner) J. Thompson foliis angustioribus, floribus et fructibus parvioribus, a $N$. mjoebergii (Cheel) J. Thompson foliis grandioribus et floribus flavis, et ab ambobus sepalis sericeis, differt.

HolOTYPE: QUeENSLAND: $2 \mathrm{~km}$ E of Merapah Station on the track to Rokeby, $13^{\circ} 43^{\prime} \mathrm{S}$, $142^{\circ} 25^{\prime}$ E, J.R. Clarkson 7142 and B.K. Simon, 10.5.1987 (BRI).

IsOTYPES: AD, CANB, CHR, DNA, K, L, MBA, MEL, MO, NSW, PERTH, QRS.

Shrub or small tree to $6 \mathrm{~m}$. Bark tight and hard, grey. Branchlets with a dense, short, closely appressed pubescence, glabrescent. Leaves sessile, oblanceolate to narrow-elliptic, often somewhat falcate, (15-)20-30(-40) $\mathrm{mm}$ long, $2-4(-5) \mathrm{mm}$ wide, sericeous, glabrescent; base attenuate; apex narrowly acuminate, somewhat pungent. Flowers borne singly on short, axillary, bracteate shoots; bracts and bracteoles scarious, brown, sericeous, caducous; hypanthium broadly funnel-shaped, 2.5-3 $\mathrm{mm}$ long, 4-4.5 $\mathrm{mm}$ diam. at the apex, densely sericeous; sepals suborbicular, 3-3.5 mm long, densely sericeous; petals orbicular, 5-5.5 mm long, yellow. Filaments 1-3 mm long; terminal gland spherical; anther-cells diverging, separate, on opposing sides of the gland, 0.3-0.4 mm long. Ovary 5-8-locular; top of the ovary slightly raised and lobed, sericeous; style 2.5-3 mm long; stigma c. $0.5 \mathrm{~mm}$ wide, slightly wider than the apex of the style. Fruit 5-6 mm diam., sericeous, glabrescent; base broadly cupular; valves equal to or slightly longer than the base. Seeds c. $2 \mathrm{~mm}$ long excluding the wing, $1.5-1.8 \mathrm{~mm}$ wide, dark reddish-brown; wing c. $3 \mathrm{~mm}$ long, c. $2 \mathrm{~mm}$ wide. (Fig. $2 \mathrm{~d} \&$ Fig. $4 \mathrm{~m}-\mathrm{r}$ ).

Flowering AND Fruiting Periods: Flowering occurs from May to July or occasionally August. Fruits persist until October or November and are shed before flowering the following year.

DisTRIBUTION: Central and southern inland areas of Cape York Peninsula between latitudes $13^{\circ}$ and $16^{\circ}$ South.

ECOLOGY: Occurs in Eucalyptus woodlands usually on shallow sandy soils derived from sandstone. The soil surface is often strewn with quartzose pebbles.

CONSERVATION STATUS: This species rates as $3 \mathrm{R}$ using the criteria of Thomas and McDonald (1987). No populations are known from within a proclaimed conservation reserve but it is highly likely the plant occurs within the Rokeby National Park.

NoTES: Until recently this plant has been infrequently collected and confused with $N$. myrtifolia from which it is distinguished by its narrow leaves, smaller flowers and fruits and 5-8-locular ovary. The hoary appearance of the sepals due to the sericeous indumentum serves to separate the new species from both $N$. myrtifolia and $N$. mjoebergii.

ETYMOLOGY: The specific epithet is based on the latin 'sericus' referring to the silken hairs on the sepals which readily distinguish the species from the other known species of the genus.

SPECIMENS SEen: 14. 


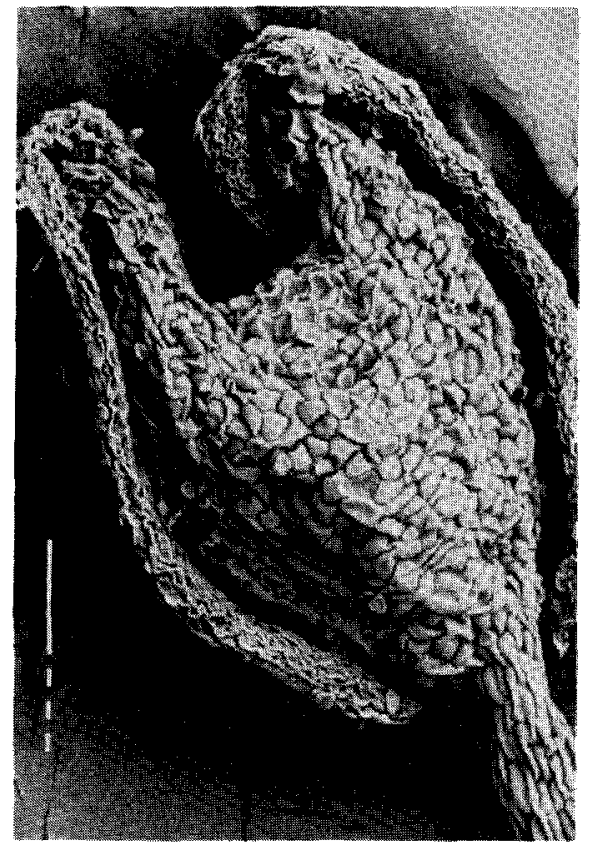

a

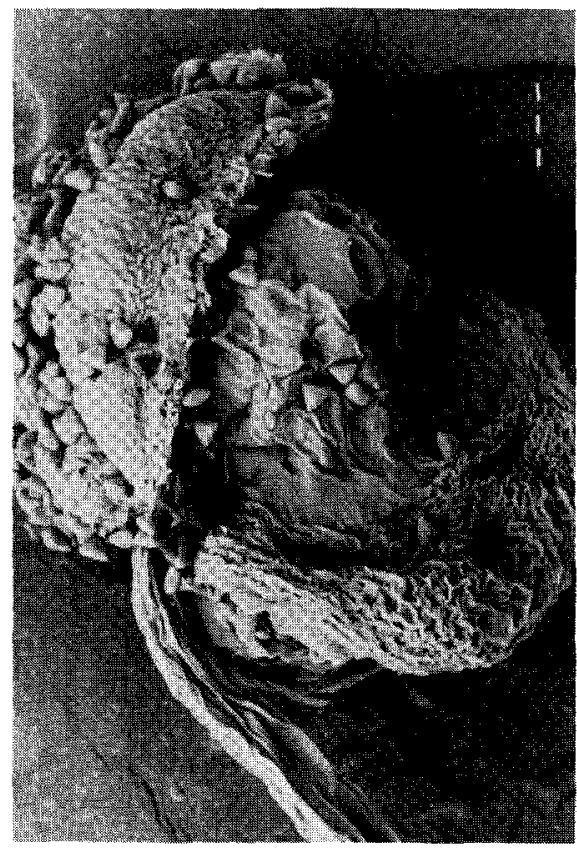

C

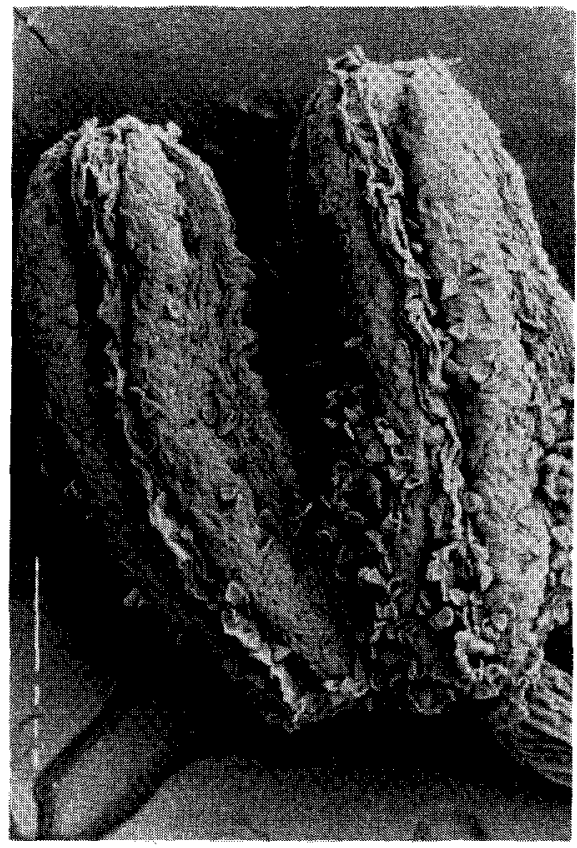

b

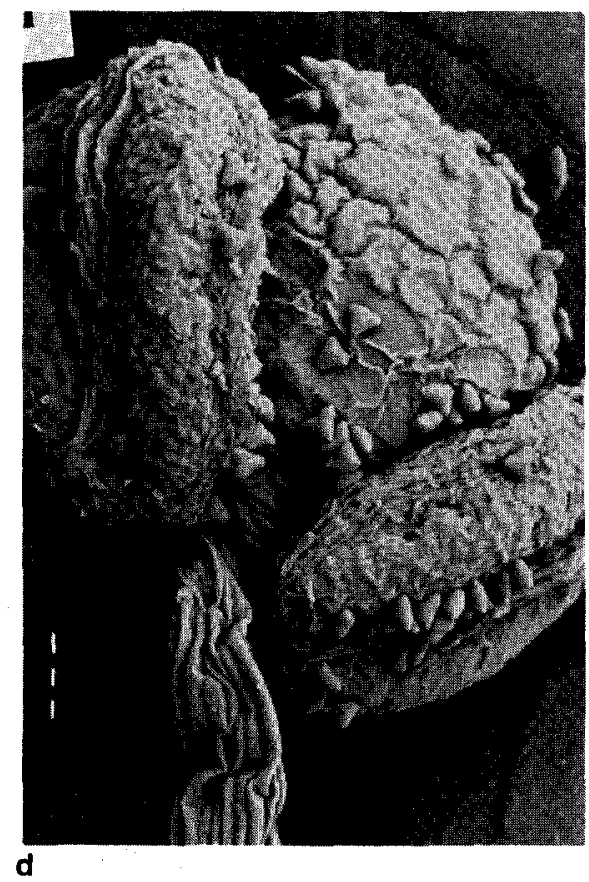

Fig. 2. Scanning electron micrographs of anthers of Neofabricia species. a, b anther of $N$. myrtifolia (top bar $=100 \mu \mathrm{m}$ ); $\mathbf{c}$ anther of $N$. mjoebergii (bottom bar $=10 \mu \mathrm{m}$ ); $\mathbf{d}$ anther of $N$. sericisepala (top bar $=10 \mu \mathrm{m}$ ); (a, b from Gittins 1802; c from Gittins 1879; $\mathrm{d}$ from Clarkson 7142 \& Simon). 
Selected Specimens: $7.8 \mathrm{~km} \mathrm{~N}$ of the Archer River on the Peninsula Development Road, Clarkson 6041, 25.7.1985 (BRI, K, MBA, MEL, NSW, QRS); $3.6 \mathrm{~km}$ E of Lukin River on Edward River to Musgrave road, Clarkson 3573, 14.10.1980 (BRI, CANB, K, MBA, MO, NA, NSW, NT, PERTH, QRS); range between Isabella Creek and Normanby River, Stephens CAIRNS 14953, 30.5.1968 (QRS); $1.7 \mathrm{~km} \mathrm{E} \mathrm{of} \mathrm{the}$ Normanby River on the Laura to Cooktown Road, Clarkson 5977, 5.6.1985 (BRI, CANB, DNA, K, L, MBA, MEL, MO, NSW, PERTH, QRS); $41 \mathrm{~km} \mathrm{~S} \mathrm{of} \mathrm{Laura} \mathrm{on} \mathrm{the}$ Maytown road, Searle SDS 998, 1.10.1984 (MBA).

3. N. myrtifolia (Gaertner) J. Thompson, Telopea 2(4): 380 (1983).

BASIONYM: Fabricia myrtifolia Gaertner, Fruct. Sem. Pl, 1: 175, t. 35, (1788).

HolotYPE: Endeavour River, Banks \& Solander, 1770, n.v. IsOTYPE: NSW.

SYNONYM: Philadelphus myrtifolius Solander ex Gaertner, loc. cit., nom. nud.

Leptospermum fabricia Benth., Fl. Austral. 3: 102 (1867). TYPE: As above.

Shrub or tree to $5 \mathrm{~m}$, occasionally reaching $10 \mathrm{~m}$. Bark hard, dark grey-brown to almost black. Branchlets glabrous or with a mixed indumentum of both long and short spreading hairs, glabrescent, the shorter hairs persisting longer. Leaves sessile or very shortly petiolate, oblanceolate to narrowly obovate, (20-) 35-45 (-55) $\mathrm{mm}$ long, (4-)6-10(-13) $\mathrm{mm}$ wide, glabrous or sericeous when young particularly along the margin; base attenuate; apex obtuse to broadly acute or acuminate. Flowers borne singly on condensed bracteate shoots at branch ends; bracts and bracteoles scarious, brown, with a fine rather spreading pubescence, caducous; hypanthium almost hemispherical above a short stout basal part, 4-5 $\mathrm{mm}$ long, 6-8 $\mathrm{mm}$ diam. at the apex, with a dense, long, appressed or spreading pubescence; sepals almost orbicular or broader than long, 3(-5) $\mathrm{mm}$ long, usually glabrous apart from the densely pubescent margins, occasionally shortly pubescent; petals almost orbicular, $8-10(-12) \mathrm{mm}$ long, yellow. Filaments 3-10 mm long; terminal gland elliptic; anther cells parallel and usually touching on the same side of the connective, $0.6-0.8 \mathrm{~mm}$ long. Ovary 8-12-locular; top of the ovary raised and lobed, usually with a dense, rather crisped pubescence; style c. $2.5 \mathrm{~mm}$ long; stigma $0.8-0.9 \mathrm{~mm}$ wide, much wider than the apex of the style. Fruit 7-9 mm diam., with a fine spreading pubescence, glabrescent; base broadly cupular; valves equal to or slightly longer than the base. Seeds $2-2.5 \mathrm{~mm}$ long excluding the wing, 1-1.5 $\mathrm{mm}$ wide, reddish brown; wing 5-6 $\mathrm{mm}$ long, 2.5-3 $\mathrm{mm}$ wide. (Fig. 2a-b, Fig. 3 \& Fig. 4a-f).

Flowering ANd Fruiting Periods: The peak of flowering occurs from May to August with occasional plants flowering somewhat earlier. Fruits appear to be retained longer than those of the other two species and, although usually shed by the start of the next season's flowering, may at times be retained.

DisTRIBUTION: Eastern and northern areas of Cape York Peninsula from Horn Island south to near Cooktown between latitude $10^{\circ} 30^{\prime}$ and $15^{\circ} 30^{\prime}$ South and on some continental islands off the east coast.

ECOLOGY: Occurs on exposed rocky headlands and in heath communities on coastal dunes where it is often one of the dominant species. North of the Wenlock River it is a common understorey element in Eucalyptus open forests and woodlands on sandy soils.

CONSERVATION STATUS: Widespread and not considered at risk. The species has been recorded from a number of proclaimed conservation reserves. 
NoTES: This is the most widespread of the three species. The habit and general morphology of the plant is quite variable. On exposed headlands plants can be rendered almost prostrate by the shearing effects of strong winds, while in coastal dune communities the habit is generally shrubby. In less exposed, tree-dominated communities further inland plants usually grow as small trees.

The leaves of plants occurring in coastal areas, particularly towards the southern limit of the species' distribution (cf. Clarkson 5988), tend to be broader, more obtuse and generally shorter than those from open forest and woodland communities further inland (cf. Clarkson 6127) and more closely resemble the form figured by Banks and Solander (1901: t. 105) and Gaertner (1788: t. 35). Flowers from these southern coastal populations also tend to be somewhat larger and deeper yellow in colour. Specimens collected from a number of continental islands off the east coast have extremely small leaves (cf. Clarkson 7407 ) although equally small-leaved specimens have occasionally been collected on the mainland (cf. Pedley 2751).

Neofabricia myrtifolia is the species referred to as Black Tea-tree by Brass in his account of the 1948 Archbold expedition to Cape York (Brass 1953). Brass records the Aboriginal name for the species as 'Untarra' or 'Antarra'. Volck (cf. Volck 01511) notes that the Aborigines of the Lockhardt River area used a reddish coloured gum from this species for glueing skins to their drums.

The plant has been introduced into cultivation where it has proved to be an adaptable species which will grow well in districts subject to no more than light frosts.

SPECIMENS SEEN: 85.

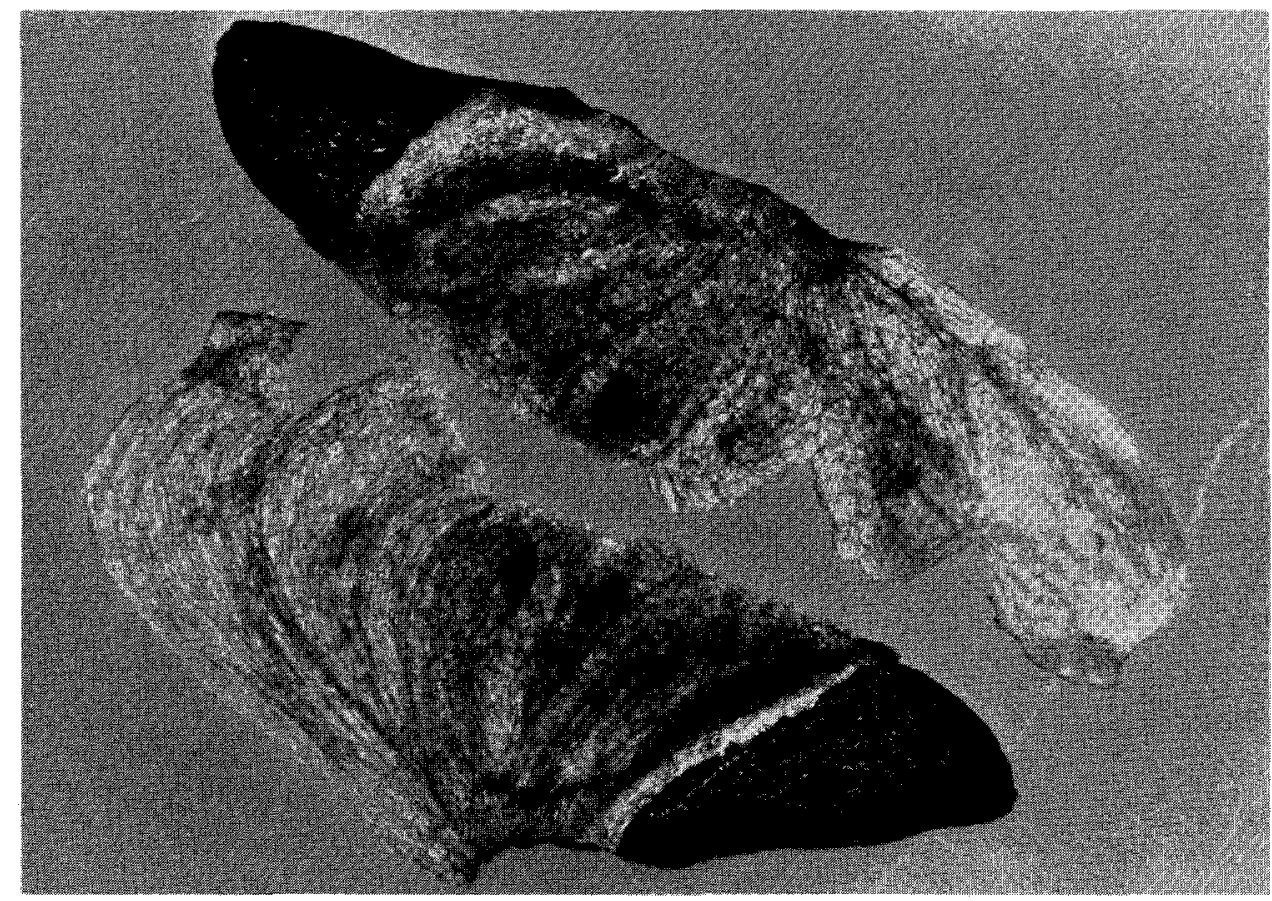

Fig. 3. Light micrograph of seed of N. myrtifolia (approx. $\times 15.5$ ). From Clarkson 3642. 


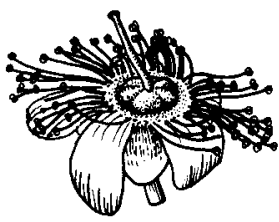

g

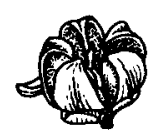

$\mathbf{h}$

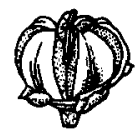

i
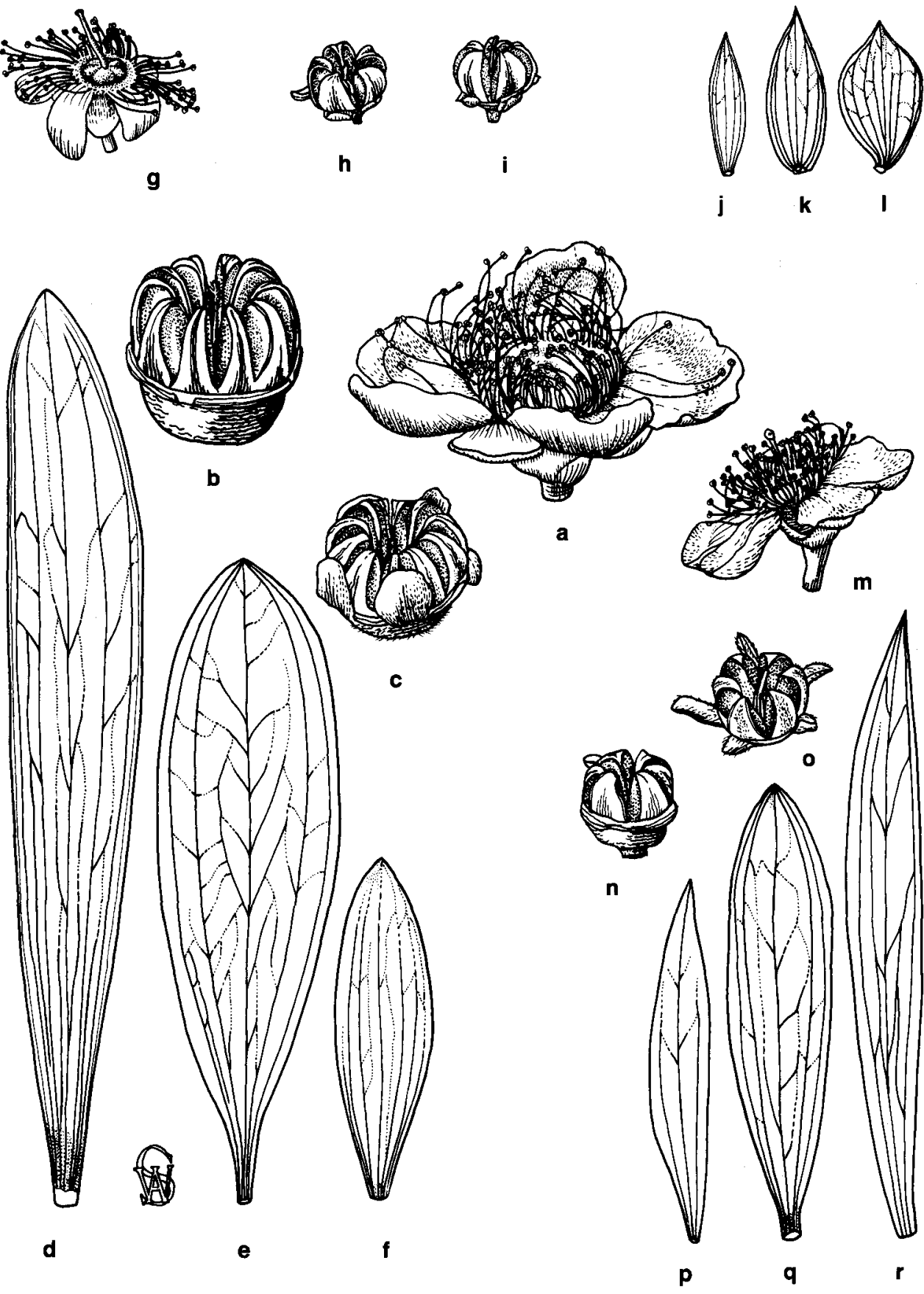

Fig. 4. Flowers, fruit and leaves of Neofabricia species (x2.5). a-f $N$. myrtifolia; g-l $N$. mjoebergii; m-r N. sericisepala; (a from Clarkson 7312 \& Jacobs; b, e from Clarkson 7294 \& Jacobs; c, d from Clarkson 6141; f from Clarkson 7407; g, l from Clarkson 3503; h, k from Gasteen 719; i from Clarkson 7313 \& Jacobs; j from Clarkson 3184; m, o, p from Clarkson 7142 \& Simon; n from Clarkson 3573; q from Clarkson 5977; r from Clarkson $7179 \&$ Simon). 
SElected SPeCimens: Horn Island, Tyack Bake [AQ 041532 (BRI)], 11.7.1943 (BRI); 1.5 $\mathrm{km} \mathrm{S}$ of the Dulhunty River crossing on the Peninsula Development Road, Clarkson 6127, 27.8.1985 (BRI, MBA, NSW, PERTH, QRS); Forbes Island, Clarkson 7407, 28.11.1987 (BRI, MBA, NSW, QRS); between Pine River basin and Gulf coast $N$ of Duyfken Point, Morton AM1117, 17.2.1981 (BRI); Iron Range, Brass 19099, 8.6.1948 (BRI); c. 30 miles WSW of Portland Roads, Pedley 2751, 1.7.1968 (BRI, NSW, QRS); 7 $\mathrm{km}$ N of upper crossing of Massey Creek on Silver Plains Station, Clarkson 3642, 12.11.1980 (BRI, K, MBA, MO, NSW, NT, PERTH, QRS); $6 \mathrm{~km}$ E of the Hopevale to Starke road on the track to the mouth of the McIvor River, Clarkson 5988, 7.7.1985 (BRI, K, L, MBA, MEL, NSW, PERTH, QRS).

\section{Acknowledgements}

Thanks are due to the Director of the Queensland Herbarium for the loan of material and to Dr B.P.M. Hyland of CSIRO Atherton for allowing free and ready access to the collection and facilities at QRS. Figure 4 was prepared by $\mathrm{Mr}$ W.A. Smith of the Queensland Herbarium and the light and electron micrographs for Figures 2 and 3 by Ms Z. Donabauer and Mr G. Robertson of New South Wales National Herbarium. Mr L. Pedley and Mr R. Henderson of the Queensland Herbarium and Dr P. Wilson and Dr P. Weston of the New South Wales National Herbarium kindly read and commented on the manuscript. J. Clarkson would like to acknowledge a grant from the Australian Biological Resources Study which provided financial support for technical assistance for floristic studies on Cape York Peninsula from 1981-1985, during which time much of the field work for this project was carried out.

\section{References}

Banks, J. \& Solander, D. (1901) 'Illustrations of the Botany of Captain Cook's Voyage Round the World in HMS Endeavour in 1768-71'. Part 11 (Trustees of the British Museum: London).

Bentham, G. (1867) 'Flora Australiensis'. Vol. 3 (Lovell Reeve: London).

Brass, L.J. (1953). Results of the Archbold expeditions. No. 68. Summary of the 1948 Cape York (Australia) expedition. Bulletin of the American Museum of Natural History 102: 141-205.

Briggs, B.G. \& Johnson, L.A.S. (1979) Evolution in the Myrtaceae - evidence from inflorescence structure. Proc. Linn. Soc. New South Wales 102: 157-256.

Gaertner, J. (1788) 'De Fructibus et Seminibus Plantarum'. Vol. 1 (Stuttgart).

Thomas, M.B. \& McDonald, W.J.F. (1987) 'Rare and Threatened Plants of Queensland'. (Queensland Department of Primary Industries: Brisbane).

Thompson, J. (1983) Redefinitions and nomenclatural changes in the Leptospermum suballiance of Myrtaceae. Telopea 2(4): 379-383.

\section{List of specimens examined}

\section{Neofabricia myrtifolia}

Anon 214 BRI; *Banks \& Solander sn; Benson D.H. 604; Blake S.T. 20261; Brass L.J. sn [AQ 325821 (BRI)], 18516, 18754, 18876, 18941, 19099, 19395, 19649; Briggs B.G. 7301, 7360; Cameron E. 2106; Clarkson J.R. 2182, 3642, 3936, 5157, 5334, 5654, 5988, $6049,6127,6141,6148,6254,6507,6508,6509,7391,7407,7415$; Clarkson J.R. 7294 \& S. Jacobs; Clarkson J.R. 7312 \& S. Jacobs; Clarkson J.R. 7327 \& S. Jacobs; Clarkson J.R. 7336 \& S. Jacobs; Dockrill A. 563, 612, 905; Dodson J. sn [AQ 0003587 (BRI)]; 
Flecker H. sn CAIRNS 13182; Gittens C.H. 1011, 1058, 1802; Hill K. 1098, L. Johnson \& D. Blaxell; Hyland B. 5509, 6225, 6455, 7466, 9006; Isbell R. 10; Johnson L.A.S. 7766; Kanis A. 1927, 2071; Maconochie J.R. 2707; McDonald T.J. \& G.N. Batianoff 1614, 1620 A; Morton A. 583, AM 1117; Musgrave A. sn NSW 183715; Paijmans K. 2781, 3025; Pedley L. 2725, 2751; Poland W. sn [AQ 41475 (BRI)]; Poland W. sn NSW 183714; Scarth-Johnson V. 868 A, 966 A, 1011 A, 1325 A; Sharpe P. 1512; Smith L.S. 12341, 12450; Stephens S.E. sn CAIRNS 11890; Stocker G. 880; Thomson D.F. 4; Tyack Bake H.T. sn [AQ 041532 (BRI)]; BRI 363346; Volck E. 01511, QF 62/58; Webb L.J. 3284; Webb L.J. \& J.G. Tracey 5988; Whitehouse F.W. sn [AQ 041531 (BRI)], AQ041044, sn [AQ 348742 (BRI)]; Young J.E. sn [AQ 041531 (BRI)].

\section{Neofabricia mjoebergii}

Brass L.J. 19983; Calderwood J.C. sn NSW 28560; Clarkson J.R. 3117, 3184, 3503, 7313; Garnett S. G2; Gasteen J. 719; Gittens C.H. 1807, 1879; Hyland B. 5230, 10066; Lavarack P.S. 1002, 1642; *Mjöberg E. sn NSW 180571; Smith L.S. 12027.

\section{Neofabricia sericisepala}

Byrnes N. 3321; Clarkson J.R. 3466, 3573, 4581, 5467, 5701, 5977, 5982, 6041; *Clarkson J.R. 7142 \& B.K. Simon; Clarkson J.R. 7179 \& B.K. Simon; Pedley L. 2664; Searle S. SDS 998; Stephens S.E. sn CAIRNS 14953.

* Indicates type.

The material examined is located at BRI, NSW, QRS or MBA. Some material, particularly that collected by J.R. Clarkson, has been widely distributed.

Manuscript received 4 March 1988

Manuscript accepted 11 January 1989 